\title{
EFL Students' Attitudes toward Authentic and Formative Assessment: The Role of Writing Rubric
}

\author{
Watcharee Kulprasit
}

\begin{abstract}
The current trend of teaching English in this century is toward authentic and formative assessment. The present study, therefore, pedagogically raises teachers' awareness of an integration of the writing rubric as an authentic and formative assessment into the EFL writing class in order to create the collaborative and interactive learning atmosphere in learning to write in English. According to the findings, the students showed positive attitudes toward the writing rubric. The role of the writing rubric changed the EFL writing class which was a grammar-based teaching to a six-trait development to improve the students' writing process and products. Through the writing rubric experience, the students' perspective on assessment was positively geared to formative assessment, an assessment that facilitated language learning and development rather than merely evaluated their final products and performance as summative assessment.
\end{abstract}

Index Terms-Authentic assessment, EFL students' attitudes, formative assessment, writing rubric.

\section{INTRODUCTION}

English is taught, learnt, and used in various contexts for achieving a variety of purposes across the world. Recently, the role of English is greatly prominent, especially in the Association of Southeast Asian Nations (ASEAN). In ASEAN, the English language is regarded as the official working language [1]. Therefore, all the countries in the group, including Thailand, pay a great deal of attention to the language. It is thus a lingua franca in practice, specifically for communication in the ASEAN context. All organizations, either in the realm of academic context or not, focus on the use of English, particularly their members' English proficiency and capacity to effectively use the language to both serve either organizations' or institutions' purposes as well as meet their personal needs.

In the Thai academic context, English is considered as the foreign language. With such significance of the English language, as EFL learners, students in Thailand have been required to study English in schools since their early ages. Concerning such a long exposure, Thai students English proficiency is, on the other hand, in the low rank compared to others countries in ASEAN. Among the four skills of English, writing, which is becoming globally important [2], is however considered to be the most difficult language skill to be developed and mastered in both foreign and second language learning including Thailand. Even in the native language itself,

Manuscript received February 9, 2016; revised March 20, 2016. This work was supported in part by Western Languages Program, Faculty of Humanities and Social Sciences, Thaksin University, Songkhla Campus.

Watcharee Kulprasit is with Thaksin University, Thailand (e-mail: mamorukeng@hotmail.com). writing is generally regarded as the first skill students have difficulty to deal with. That's why the role of teaching writing is, therefore, gaining more and more significance in both foreign and second language academic contexts [2]. When a certain skill is considered as an important skill, a process of assessment must take the role.

Assessing writing is the most rudimentary and important duty for teachers although it is time-consuming and needs a great deal of patience [3]. Teachers should be aware of their responsibility to assess students' writing. However, students themselves should be included in the process of writing assessment as well because "through assessment, most writers can learn to be more careful evaluators of their own writing as well as the writing of others" (p. 9). Regarding [2], writing assessment includes two fundamental elements: writing tasks and a tool to assess writing tasks. Traditionally, writing assessment, according to the product-based approach, is merely focused on accuracy of the writing product. Later, there is the shift from the product-based approach to the process-based approach in teaching writing. Hence, writing assessment needs to be changed to parallel the teaching approach. Authentic assessment is then developed to serve the process-based writing approach in place of the traditional assessment which merely evaluates the writing product.

The use of rubric is, therefore, remarked as a developed set of criteria, with its certain advantages to guide students to compose their writing and to help teachers assess their students' writing in the writing classroom [4]. With such an authentic tool through this process, a rubric is additionally regarded as a kind of feedback tool used for either summative or formative assessment purposes [5]. According to [6], the rubric is perceived as a tool to help save time when teachers give detailed feedback to students for they can improve their work [7]. Even emphasizes that with an integration of the rubric in learning, learning targets can be obviously perceived by students for they could realize what learning targets they have to learn, improve, and achieve. In such a case, students can develop their own learning through their own experience via the means of rubric. With this assessment method, "learning is seen as an ongoing refinement leading toward the achievement of established outcomes" [4] (p. 38). In so doing, Montgomery suggests a rubric as an authentic assessment tool to evaluate students' writing process, progress, and product according to the criteria.

Nevertheless, [8] believes that specific feedback is far more significant and effective to respond to students' writing than the use of rubric. With a certain limitation of the writing rubric though how many details it elaborates in each category we choose to value about writing; for instance, conventions, sentence fluency, organization, word choices, and etc., it 
sometimes decreases the possibility of the teacher's response to students' writing, especially when their concerning writing issue is found to be irrelevant based on the criteria being set in the rubric. Furthermore, [9] points out students need a great deal of motivation and comprehension to use the rubric efficiently in order to gain its advantages. If not, it is merely considered as "a replacement for good instruction" (p. 29) which is a wrong belief. Apart from that, validity, reliability, and fairness are the essential notions to be taken into account for an integration of the quality rubric being employed in the writing class that the teacher needs to concern.

Regarding the benefits of authentic assessment in the process writing approach, a controversial issue concerning pros and cons of the writing rubric has been widely and distinctively discussed across different settings. Few, if any, investigations of the students' attitudes toward the use of the writing rubric in the Thai EFL academic context have been rarely found. In order to bridge this gap, the present study provides an opportunity for Thai EFL students to experience the writing rubric in the writing course. In so doing, the students' attitudes toward the writing rubric can be explored.

\section{Methodology}

\section{A. Subjects}

The subjects were thirty-four English major sophomores at a university in the south of Thailand. The undergraduates were taking Basic Writing Course as a required course in the B.A. curriculum in the first semester of the academic year 2014 during the period of the study. Because the subjects were selected by a convenience sampling method, it provided a great and convenient opportunity for the researcher to access the data to answer the research questions in this study. In addition, as a researcher was an instructor in this course, any confounding variables could also be limited.

\section{B. Instruments}

In order to investigate if the subjects' attitudes toward writing in English would be positively and significantly affected by the use of the writing rubric, the research instruments mainly employed in this study were a six-trait writing rubric sheet and an attitude toward a writing rubric questionnaire.

1) A Six-Trait Writing Rubric Sheet (See Appendix A). The writing rubric employed in the present study was adapted from Teacher Six-Point Writing Guide of [10] as its characteristics were compatible with the subjects' writing qualities. According to this writing rubric, there were six traits of writing to be assessed; that is, conventions, sentence fluency, ideas, organization, word choice, and voice.

2) An Attitude toward a Writing Rubric Questionnaire (See Appendix B).

The questionnaire was developed in the form of Likert-rating scale ranging from 5 to 1 ( $5=$ strongly agree, $4=$ agree, $3=$ neutral, $2=$ disagree, $1=$ strongly disagree). The questionnaire regarded the subjects' attitudes toward the use of the writing rubric in the first section.

The second part of the questionnaire was saved to draw out the subjects' attitudes toward the use of the writing rubric in the open-ended form to avoid any constraints of the given statements in the form of Likert-rating scale questionnaire. Every section of the questionnaire was developed in both English and Thai versions. Nevertheless, only the Thai version was launched to the subjects in order to avoid any confusion, misunderstanding, or misleading at the end of the study.

\section{Data Collection}

In the first week of the first semester of the academic year 2014 , the orientation of the writing rubric as well as their benefits were enthusiastically introduced by the teacher (the researcher) to encourage the subjects to take part in the activity. From the second week to the final week, the subjects were asked to carry out a writing task in the last thirty minutes of the class. Then they used the writing rubric to assess their writing as well as their peers' for another thirty minutes. The subjects were required to do this activity weekly for approximately eight weeks. After that, they were asked to respond to the post-treatment questionnaire about their attitudes toward the writing rubric after they had some writing rubric experience.

\section{Data Analysis}

The data obtained from the attitude questionnaire were analyzed to answer the research question in this study. In order to answer the research question, the subjects' responses to the questionnaire about their attitudes toward an integration of the writing rubric in their writing were analyzed and interpreted item by item according to the criteria as shown in Table I.

TABLE I: CRITERIA FOR RATING SCALE INTERPRETATION

\begin{tabular}{|c|c|}
\hline $\begin{array}{c}\text { Range of the Total Mean Value } \\
(\overline{\mathrm{x}})\end{array}$ & $\begin{array}{c}\text { Level of Agreement } \\
4.21-5.00\end{array}$ \\
\hline $3.41-4.20$ & Strongly agree \\
\hline $2.61-3.40$ & Agree \\
\hline $1.81-2.60$ & Neutral \\
\hline $1.00-1.80$ & Disagree \\
\hline
\end{tabular}

\section{RESUlTS}

The attitude toward a writing rubric questionnaire as a post-treatment questionnaire consisted of two sections. The first section involved the subjects' attitudes toward the use of writing rubric. It consisted of twelve items with a five-point Likert scale ranging from 5 (strongly agree) to 1 (strongly disagree). Their responses were analyzed for the mean scores and demonstrated in Table II as follows.

According to Table II, the mean scores of the subjects' responses range from 4.00 to 4.45 with an average mean score of 4.27 , falling into the level of strongly agree. This finding could be interpreted that the subjects had positive attitudes toward the use of writing rubric in the writing class since they strongly agreed on the significance of an integration of the writing rubric in the writing class as well as the benefits of the writing rubric in the way that it made them realized both of their strengths and weaknesses in their writing (item 6 , item 8 , item $9, \bar{x}=4.45)$. Furthermore, the subjects also strongly 
agreed with the following statements. That is, they had the writing rubric as a guide to evaluate their own writing as well as their peers'. In so doing, their writing problems could be diagnosed (item 4 , item $5, \bar{x}=4.35$ ). That's why it should be regarded as an assessment tool to be employed in the writing class in order to help improve writing in more than one trait: grammar (item 7, item 11, $\overline{\mathrm{x}}=4.23$; item 12, $\overline{\mathrm{x}}=4.26$ ). Apart from that, the subject also agreed that the writing rubric was the most useful source of feedback which they could get to improve their writing in a wide range of traits concerning the good qualities of writing. Therefore, the writing rubric was considered as an effective tool that played an important role in the writing process to help improve their writing. This interpretation can be seen from the following items (item 1, $\bar{x}$ $=4.00$; item 2, $\bar{x}=4.10$; item $3, \bar{x}=4.13$; item 10, $\bar{x}=4.19$ ).

TABLE II: SUBJECTS' ATTITUDES TOWARD WRITING RUBRIC

\begin{tabular}{|c|c|c|c|}
\hline Statement & Mean & S.D. & $\begin{array}{c}\text { Level of } \\
\text { Agreement }\end{array}$ \\
\hline $\begin{array}{l}\text { 1. I think the writing rubric is an } \\
\text { effective tool to improve my writing } \\
\text { in general. }\end{array}$ & 4.00 & 0.73 & Agree \\
\hline $\begin{array}{l}\text { 2. I think the writing rubric plays a } \\
\text { significant role in writing process. }\end{array}$ & 4.10 & 0.75 & Agree \\
\hline $\begin{array}{l}\text { 3. I think the writing rubric helps } \\
\text { improve my writing in diverse areas } \\
\text { consisting the good qualities of } \\
\text { writing. }\end{array}$ & 4.13 & 0.67 & Agree \\
\hline $\begin{array}{l}\text { 4. With the writing rubric, I have a } \\
\text { guide to evaluate my own work and } \\
\text { my peer's work. }\end{array}$ & 4.35 & 0.61 & Strongly agree \\
\hline $\begin{array}{l}\text { 5. The writing rubric can diagnose } \\
\text { my writing problem. }\end{array}$ & 4.35 & 0.55 & Strongly agree \\
\hline $\begin{array}{l}\text { 6. All the six traits in the writing } \\
\text { rubric are important in writing. }\end{array}$ & 4.45 & 0.62 & Strongly agree \\
\hline $\begin{array}{l}\text { 7. I think the use of writing rubric } \\
\text { helps me improve my work more } \\
\text { than one trait: grammar. }\end{array}$ & 4.23 & 0.80 & Strongly agree \\
\hline $\begin{array}{l}\text { 8. Using the writing rubric, I know } \\
\text { what my writing strength is. }\end{array}$ & 4.45 & 0.57 & Strongly agree \\
\hline $\begin{array}{l}\text { 9. Using the writing rubric, I know } \\
\text { what my writing weakness is. }\end{array}$ & 4.45 & 0.57 & Strongly agree \\
\hline $\begin{array}{l}\text { 10. The writing rubric is the most } \\
\text { useful source of feedback. }\end{array}$ & 4.19 & 0.60 & Agree \\
\hline $\begin{array}{l}\text { 11. The writing rubric should be an } \\
\text { assessment tool used to evaluate } \\
\text { students' writing in the writing } \\
\text { class. }\end{array}$ & 4.23 & 0.62 & Strongly agree \\
\hline $\begin{array}{l}\text { 12. I think the writing rubric should } \\
\text { be employed in a writing class. }\end{array}$ & 4.26 & 0.68 & Strongly agree \\
\hline Average & 4.27 & 0.65 & $\begin{array}{l}\text { Strongly } \\
\text { agree }\end{array}$ \\
\hline
\end{tabular}

In sum, the subjects had positive attitudes toward the writing rubric $(\overline{\mathrm{x}}=4.27)$ because they perceived its values.
Thus, it should be integrated into the writing class in the future as an effective assessment tool to help improve their writing in different traits that served the qualities of good writing.

Apart from the five-point Likert scale section of the post-treatment questionnaire, the subjects were asked to answer an open-ended question in order to reflect their attitudes toward the employment of writing rubric in their writing course in their own words. Their responses are summarized as follows.

According to their responses, most subjects perceived the writing rubric as a standard or a criterion which they tried to make their writing quality meet. In order to reach such a goal, their work needed a certain amount of improvement. Unquestionably, the writing rubric was highlighted as an important tool to enhance their writing. With the use of the writing rubric as a guide; moreover, the subjects could analyze and realize their own weaknesses as well as their strengths in a variety of traits, so that they could develop their writing to get the high scores since they knew what they were good at and those that needed to pay more attention to apart from grammar which was the main focus in writing assessment in general. Nevertheless, some subjects pointed out that the scores they got from the writing rubric depended on the level of difficulty of each type of writing. In so doing, it increased their motivation in writing development for each genre of writing, and they found out that it was really challenging for them. More significantly, the subjects knew which level their writing proficiency or their writing performance was through the use of the writing rubric. Thus, they could build on their existing writing skill to make progress in writing. Most significantly, the writing rubric was regarded as a formative assessment for both students and the teacher and an effective feedback source to instruct them for fostering further learning.

\section{DisCUSSION AND PEDAGOGICAL IMPLICATIONS}

According to the findings, all of the subjects had positive attitudes toward the writing rubric since they appreciated its values. That is, it played a significant role in the writing process as an effective assessment tool and a useful source of feedback to improve their writing in English in terms of both their writing performance and writing products. With the writing rubric as a guide to assess their own work as well as their peers', their writing was greatly improved in various aspects apart from grammatical aspects. Additionally, the writing rubric indicated their current writing performance, quality of their writing products, strengths, and weaknesses where they could further developed. So their writing quality was generally improved. This finding is in line with [11]'s study. In the study, the undergraduate students' perspectives on rubric-referenced assessment were investigated. The students reported that they produced higher quality writing through the use of rubrics. The same finding was also found in [12]'s study. [12] carried out a research concerning the use of a writing rubric and a progress record sheet to help improve college students' writing. The students'a attitudes toward the use of the writing rubric were examined. The results 
demonstrated that the college students had positive attitudes towards the writing rubric. It was considered as a guide and a reflective as well as assessment tool to help improve their writing in English. That's why the students reported that they had more confidence in writing in English. Interestingly, a different result was, nonetheless, found out in [13]'s study. In [13]'s study, the impact of the writing rubric on the college students' quality of writing, self-efficacy, and writing practices were investigated. The finding, nevertheless, revealed that the use of the writing rubric had no significant effect on the students' writing quality. Particularly, the length of the rubric was not related to the students' better writing performance. However, the writing rubric used as a formative assessment provided informative feedback to generally foster the subjects' writing proficiency in the study. However, this supports what [9] pointed out that the two most effective ways to integrate the writing rubric into the classroom: the use of the rubric as a summative assessment by a teacher and the use of the rubric to support self-assessment, peer-assessment, and teacher-assessment as they were also revealed in the present study. In addition, [14]'s study also emphasized this benefit of the rubric; that is, it was a tool for self-assessment and peer feedback as well as a formative assessment to foster students' writing improvement in terms of both performance and products.

The positive impact of an integration of the writing rubric in the current study suggests pedagogical implications for teaching writing more effectively, particularly in the academic context where English is taught as a foreign language.

\section{A. From Teaching Grammar in Writing to Developing Six Traits of Good Writing}

In the Thai academic context where English is taught as a foreign language, teaching English is practically teaching grammar in the target language. Thus, the students learn about the language, not how to communicate with the target language. Undoubtedly, Thai students cannot speak or write English though they have learned the language for a long time. Moreover, writing is unquestionably considered as the last language skill to master even in the native language and the least preferred language skill to study in the target language. An implication of the writing rubric in teaching writing, consequently, shifts the focus of teaching writing in English from teaching grammar to developing the students' writing containing the six traits that are considered as good elements in writing. With the writing rubric, their quality of writing products is not only improved in terms of grammar, but also organization, word choice, etc.

\section{B. Self-Assessment via the Use of the Writing Rubric}

Self-assessment employed in the present study emphasizes its major benefit in the way that it promotes autonomous learning. Since the students must assess their own writing based on the writing rubric, they learn to be aware of both their strengths and weaknesses in order to build up their writing performance based on their current writing proficiency. This develops self-editors who take responsibility of their own learning to produce better writing products with less assistance from teachers or friends. This self-improvement also fosters student-centered language teaching in the writing class.

\section{Peer-Assessment and Collaborative and Interactive Atmosphere}

Teacher-directed language teaching method is commonly found in the Thai academic context. Hence, it is quite difficult to provide an opportunity for the students to take responsibility of their own learning without an intervention. An integration of peer-assessment in the present study helps decrease the role and authority of the teacher in the classroom for the students to take charge of their own language learning and improvement. This additionally promotes collaborative and interactive atmosphere in the language classroom, especially in the writing class where positive attitudes toward collaborative and interactive activity and peer facilitation can be developed. Sooner or later, their positive attitudes toward such a learning environment help boost their positive attitudes toward writing.

\section{CONCLUSION}

The present study is significant in its nature. It is one of the first few, if any, to investigate the attitudes of EFL students toward the writing rubric in the Thai academic context. Regarding the findings and certain limitations of the study, some recommendations for further studies are given to shed light on the following aspects.

1) The correlation between the students' attitudes toward the writing rubric and their competence in writing in English should be considered in the future study to see if they are significantly related or not.

2) To confirm the findings of the present study, this study should be replicated with the larger sample size at different levels of education for a longer period of time in different academic contexts to see whether the same findings will be produced; that is, whether the students will have positive attitudes toward an integration of the writing rubric in the writing class or not.

\section{APPENDIX}

APPENDIX A: A SiX-TRAit WRITING RUBRIC SHEET

\begin{tabular}{|c|c|c|c|c|c|c|c|c|c|}
\hline & 6 & 5 & 4 & 3 & 2 & 1 & Self & Peer & Teacher \\
\hline Conventions & $\begin{array}{l}\text { Thoroughly } \\
\text { edited - only } \\
\text { the pickiest } \\
\text { editors will } \\
\text { spot errors }\end{array}$ & $\begin{array}{l}\text { Edited well - } \\
\text { minor errors } \\
\text { that are } \\
\text { easily } \\
\text { overlooked }\end{array}$ & $\begin{array}{l}\text { Errors do not } \\
\text { interfere } \\
\text { with } \\
\text { meaning }\end{array}$ & $\begin{array}{l}\text { Errors may } \\
\text { slow reader or } \\
\text { affect } \\
\text { message in } \\
\text { spots }\end{array}$ & $\begin{array}{l}\text { Minimal } \\
\text { editing - } \\
\text { frequent, } \\
\text { distracting } \\
\text { errors }\end{array}$ & $\begin{array}{l}\text { Not edited } \\
\text { yet - } \\
\text { serious, } \\
\text { frequent } \\
\text { errors }\end{array}$ & & & \\
\hline $\begin{array}{l}\text { Sentence } \\
\text { Fluency }\end{array}$ & $\begin{array}{c}\text { Lyrical - } \\
\text { dances along } \\
\text { like a script, } \\
\text { poem, or song }\end{array}$ & $\begin{array}{l}\text { Easygoing } \\
\text { rhythm, flow, } \\
\text { cadence - } \\
\text { significant }\end{array}$ & $\begin{array}{c}\text { A few } \\
\text { awkward } \\
\text { moments - } \\
\text { some variety }\end{array}$ & $\begin{array}{c}\text { Mechanical } \\
\text { but readable - } \\
\text { little variety in } \\
\text { style }\end{array}$ & $\begin{array}{l}\text { You can } \\
\text { read it if } \\
\text { you're } \\
\text { patient and }\end{array}$ & $\begin{array}{c}\text { Hard to } \\
\text { read, even } \\
\text { with effort } \\
-\end{array}$ & & & \\
\hline
\end{tabular}




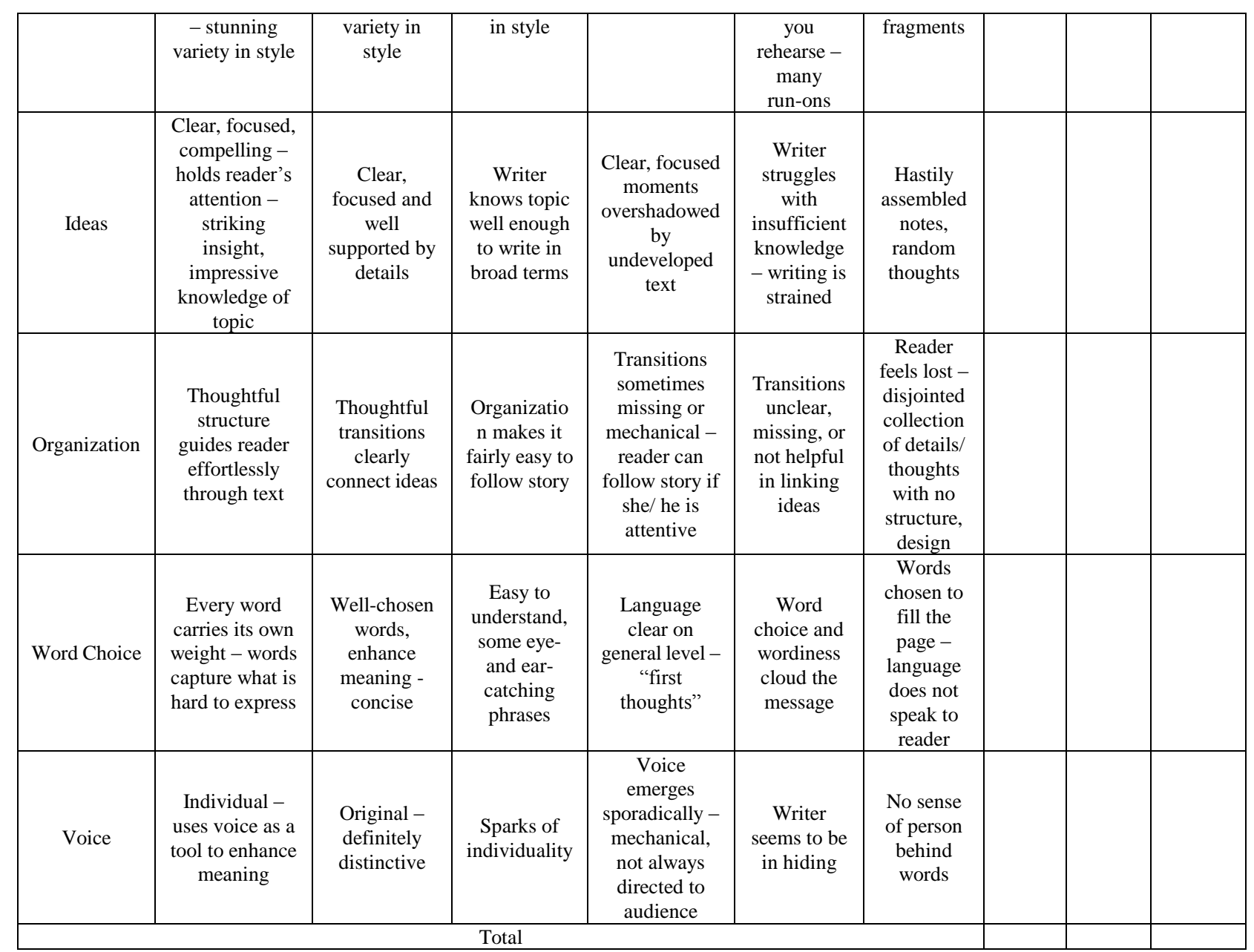

Appendix B: An Attitude toward a Writing Rubric Questionnaire

English Version:

Attitude Questionnaire

Part I: Attitude toward a Writing Rubric

\begin{tabular}{|c|c|c|c|c|c|c|}
\hline \multirow[b]{2}{*}{ No. } & \multirow[b]{2}{*}{ Statement } & \multicolumn{5}{|c|}{ Level of Agreement } \\
\hline & & 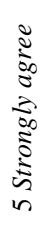 & $\begin{array}{l}0 \\
\frac{0}{\pi} \\
\dot{\sigma} \\
\dot{\sigma}\end{array}$ & 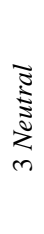 & 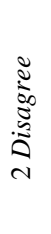 & 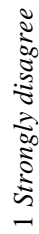 \\
\hline 1 & $\begin{array}{l}\text { I think the writing rubric is an effective tool to improve my writing in } \\
\text { general. }\end{array}$ & & & & & \\
\hline 2 & I think the writing rubric plays a significant role in writing process. & & & & & \\
\hline 3 & $\begin{array}{l}\text { I think the writing rubric helps improve my writing in diverse areas } \\
\text { consisting the good qualities of writing. }\end{array}$ & & & & & \\
\hline 4 & $\begin{array}{l}\text { With the writing rubric, I have a guide to evaluate my own work and my } \\
\text { peer's work. }\end{array}$ & & & & & \\
\hline 5 & The writing rubric can diagnose my writing problem. & & & & & \\
\hline 6 & All the six traits in the writing rubric are important in writing. & & & & & \\
\hline 7 & $\begin{array}{l}\text { I think the use of writing rubric helps me improve my work more than one } \\
\text { trait: grammar. }\end{array}$ & & & & & \\
\hline 8 & Using the writing rubric, I know what my writing strength is. & & & & & \\
\hline 9 & Using the writing rubric, I know what my writing weakness is. & & & & & \\
\hline 10 & The writing rubric is the most useful source of feedback. & & & & & \\
\hline 11 & $\begin{array}{l}\text { The writing rubric should be an assessment tool used to evaluate students' } \\
\text { writing in the writing class. }\end{array}$ & & & & & \\
\hline 12 & I think the writing rubric should be employed in a writing class. & & & & & \\
\hline
\end{tabular}


Part II: Answer the following questions in detail.

Do you think that the writing rubric helps improve your textual quality? If so, in what ways? If not, why not?

\section{REFERENCES}

[1] A. Kirkpatrick, "English as the official working language of the association of southeast Asian nations (ASEAN): Features and strategies," English Today, vol. 24, no. 2, pp. 27-34, 2008.

[2] S. Weigle, Assessing Writing, Cambridge: Cambridge University Press, 2002.

[3] D. Crusan, Assessment in the Second Language Writing Classroom, USA: The University of Michigan Press, 2010.

[4] K. Mongomery, "Authentic tasks and rubrics: Going beyond traditional assessments in college teaching," College Teaching, vol. 50, no. 1, pp. 34-39, 2002.

[5] M. Overmeyer, What Student Writing Teaches Us: Formative Assessment in the Writing Workshop, Colorado: Stenhouse Publishers, 2009.

[6] D. D. Stevens and A. J. Levi, Introduction to Rubrics: An Assessment Tool to Save Grading Time, Convey Effective Feedback and Promote Student Learning, Virginia: Stylus Publishing, LLC, 2005.

[7] S. M. Brookhart, How to Create and Use Rubrics for Formative Assessment and Grading, USA: ASCD, 2013.

[8] M. Wilson, "Why I won't be using rubrics to respond to students' writing," English Journal, vol. 96, no. 4, pp. 62-66, 2007.

[9] H. G. Andrade, "Teaching with rubrics: The good, the bad, and the ugly," College Teaching, vol. 53, no. 1, pp. 27-30, 2005.

[10] V. Spandel, Creating Writers through 6-Trait Writing: Assessment and Instruction, USA: Pearson Education, Inc, 2009.

[11] H. Andrade and Y. Du, "Student perspectives on rubric-referenced assessment," Practical Assessment Research \& Evaluation, vol. 10, no. 3, pp. 1-11, 2005.
[12] A. Hisatsune, "Better writing with a writing rubric," in Proc. International JALT 2007 Conference, 2008, pp. 913-925.

[13] A. E. Covill, "College students' use of a writing rubric: Effect on quality of writing, self-efficacy, and writing practices," The Journal of Writing Assessment, vol. 5, no. 1, pp. 1-12, 2012.

[14] K. Wolf and E. Stevens, "The role of rubrics in advancing and assessing student learning," The Journal of Effective Teaching, vol. 7, no. 1, pp. 3-14, 2007.

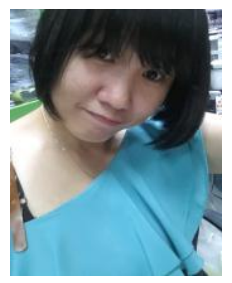

Watcharee Kulprasit was born in Songkhla, Thailand on July 21, 1982. She holds a B.A. (First class honors) degree in English from Thaksin University, Songkhla Campus, Thailand in 2005 and a M.A. degree in teaching English as an international language from Prince of Songkla University, Hat-Yai Campus, Songkhla Thailand in 2012.

Currently, she is working as a lecturer in the Western Languages Program, Faculty of Humanities and Social Sciences, Thaksin University, Songkhla Campus, Thailand. Her previous published research articles include: 1). "Using Journal Writing with Peer Feedback to Enhance EFL Students' Writing Ability Across Proficiency Levels," PASAA, vol. 45, pp. 91-111, January 2013; 2). "Boosting EFL Students' Positive Attitudes toward Writing in English: The Role of Journal Writing with Peer Feedback," ABAC Journal, vol. 32, no. 3, pp. 20-28, September-December 2012. Her current interests are English writing, language assessment, literature, and creative writing.

Ms. Kulprasit has won the Best Thesis Award under the thesis title: "Impacts of Journal Writing with Peer Feedback on EFL Students' Writing Ability” from PSU Research and Innovation Award 7 in 2013. 